\title{
PEOPLE EMPOWERMENT STRATEGIES THROUGH THE MOSQUES: CASE STUDY OF MASJID AL-JIHAD BRAYAN MEDAN
}

\author{
Andri Soemitra \\ The Writer is lecturer in IAIN Sumatera Utara, Ph.D in Islamic Economics, \\ Current position as Vice Dean I The Faculty of Shariah, \\ IAIN Sumatera Utara \\ andrisoemitra@gmail.com
}

Abstract: Fakta saat ini menunjukkan bahwa di Indonesia tidak banyak program dan agenda pemberdayaan masyarakat dan pemberantasan kemiskinan yang menggunakan ajaran agama dan institusinya sebagai paradigma berfikir dan instrumennya. Padahal, sebagai negara dengan mayoritas penduduk beragama Islam, Indonesia memiliki kesempatan emas untuk melibatkan agama dan institusi agama dalam berbagai program dan strategi pemberdayaan masyarakat dan pemberantasan kemiskinan. Tulisan ini memperkuat tesis bahwa masjid sebagai institusi agama Islam memiliki potensi yang luar biasa apabila difungsikan sebagai salah satu instrumen strategi pemberdayaan masyarakat dan pemberantasan kemiskinan. Tesis penelitian ini dibuktikan lewat penelitian empiris pada Masjid Al-Jihad Pulo Brayan kota Medan. Hasil penelitian empiris memperkuat tesis penelitian ini bahwa program dan strategi pemberdayaan masyarakat dan pemberantasan kemiskinan lewat pendirian BMT Masjid Al-Jihad memberikan hasil yang positif dan dapat menjadi model pelibatan masjid dalam program pemberdayaan masyarakat dan pemberantasan kemiskinan.

Kata Kunci: masjid, pemberdayaan masyarakat, pengentasan kemiskinan.

\section{A. InTRODUCTION}

Eighty percent of the world's population professes religious faith, including 1.3 billion Muslims worldwide (20 per cent of the global population). Nearly 70 per cent of all Muslims live in Asia (including the Middle East), while just over a quarter live in Africa. A new Pew Forum graphic shows that Indo- 
nesia is the country with the world's largest Muslim population. Roughly $88 \%$ of Indonesia's population is Muslim, and the nation is home to about $13 \%$ of the world's Muslims. (Pew Research's Center Religion and Public Life: 2010) Indonesia Muslims nearly 234 million Muslims make it the country with the highest number of adherents to this religion. However, According to government figures, $14.15 \%$ of Indonesians ( 32.5 million) live below the national poverty line and approximately half of all households remain clustered around the national poverty line set at 200,262 rupiahs per month (\$22) (The World Bank, 2013). This is a very big challenge that must be solved because the majority of Indonesians are Muslims.

Ever since the Asian economic crisis in 1997/98, poverty reduction has been at the heart of government's policy agenda, which has seen various programs to protect the poor through the provision of rice, health and education and the empowerment of communities and business. However, religious teaching and belief has long been ignored in mainstream development paradigms and by development practitioners. The values and attitudes associated with religious beliefs within countries can affect both public policy settings as well as social behaviours. However, religious teaching and belief are not explicitly considered within mainstream development agendas in poverty alleviation programs and agendas.

This paper is interested in the mosque role in poverty alleviation. In particular this paper is interested in positioning mosque as a poverty alleviation agent aligns with poverty alleviation as understood within Islamic religious teaching. With almost 1,000 mosques all around Indonesia, it can be a great opport unity for mosques to be very effective tools for reducing Muslims' poverty community in Indonesia through productive charity and microfinance program. This paper will propose a model that promote mosque as agent for poverty reduction. This paper argued that applied Islamic religious teaching can be positive and constitutive force that can be harnessed to improve the material lives of the needy. The method that is used in this paper is qualitative method with interview as the main data collection method.

\section{B. Literature ReVieW}

Many literatures have written on economic development in Indonesia. However, most of them are ignoring religious teaching and belief as their paradigm and programs. Only a few literatures that consider religious teaching and belief in their development paradigms and programs. 
Shofwan Al Banna Choiruzzad in his essay entitled "More Gain, More Pain: The Development of Indonesia's Islamic Economy Movement (1980s2012)." This essay offers a comprehensive picture of the development of the Islamic economy movement in Indonesia from its early stages (in the 1980s) until the present. The paper traces the development of the movement chronologically and elaborates the social and political dynamics that influenced this development through its various stages. It argues that Indonesia's Islamic economy movement had undergone significant changes, both in rhetoric and structure, as a result of interactions between different advocates representing the state and civil society, as well as business entrepreneurs (Shofwan Al Banna Choiruzzad, 2013).

Aimatul Yumna and Matthew Clarke in their paper entitled "Integrating zakat and Islamic charities with microfinance initiative in the purpose of poverty alleviation in Indonesia.” This paper explores examples of how Islamic principles of charity and finance can strengthen microfinance as a poverty alleviation strategy. It describes two cases study of Baitul Maal Muamalat Indonesia and Baitul Qiradh Baznas in Indonesia. The study shows although they have utilized zakat and Islamic charities as microfinance's source of fund, they only targeted low income people with some form of employment. It can be argued that zakat and Islamic charities should be functioning as an additional fund to provide social services for the extremely poor and combined it with the commercial fund to achieve better outcomes in poverty reduction (Aimatul Yumna and Matthew Clarke, 2012).

Sayuti Hasibuan in his paper entitled "Poverty Alleviation: The Islamic Way," argued that poverty in Muslim countries can be eradicated in a sustainable manner. For this we need to change the paradigmatic societaldevelopmental process from the basically capitalistic system obtaining in Muslim countries to Islamically consistent human resource based societal development process. The paper examined the meaning of the change. This means examining not only the identification of the relevant capitalistic as compared to the Islamic characteristics of societal development system; but also expounding the content and the processes of the change. A basic characteristic difference lies in the source of knowledge and its development to guide actions in the capitalistic system as compared to the Islamic system: the former is based on the idea of materialism while the latter is based on human development. Zakat and waqf will be indispensable components of the human based development system (Sayuti Hasibuan, 2010). 
Muhammad Ramzan Akhtar in his paper entitled "Poverty Alleviation on a Sustainable Basis in the Islamic Framework," presented an Islamic approach of poverty alleviation on sustainable basis. The paper finds major problems in existing approaches wherein poverty alleviation is neither sought as a policy goal nor is addressed in correct ways. In fact, the focus has remained on assisting needy people through grants and financing small units through microcredit and soft loans schemes. The paper suggests two-pronged approach: one is accelerating growth favouring poor and second is systematically extending them education, health, and drinking water facilities. For implementing this approach the paper suggests starting of Islamic banking system, instituting of guarantee agency, and welfare budget in the country. The paper believes that policy actions on these lines will alleviate poverty on sustainable basis (Muhammad Ramzan Akhtar, 2000).

Ismail Sirageldin in his paper entitled "Elimination of Poverty: Challenges and Islamic Strategies." He focused on four basic tenants of the Islamic ethical system and treats the Islamic ethos as an ideal, through which socioeconomic policies dealing with poverty elimination are assessed. Islam views society as a unified equity in which individual freedom and human dignity is supreme although subject to the axiom of responsibility. These ethical tenants indicate that policies should not develop 'dependency' or amoral activities. Policies should not lead to the institutionalization of poverty. Policies based on transfers that do not lift the poor from their dependency status should not be adopted except in cases where such shift is not feasible. Based on the conceptual and empirical evidence, the paper concludes that Islamic ethics support a povertyalleviation strategy based on the principle of promoting economic growth with productive equity (Ismail Sirageldin, 2000).

Those literatures above have accommodated Islamic teaching and belief as their paradigm and programs in poverty alleviation. This paper will focus on the function of mosque not only as worship place for Muslims but also as the important tool for poverty eradicating through inserting productive programs in the mosque.

\section{Functions of Mosque in Islam}

The word of mosque comes from the Arabic word masjid. In a narrow concept, mosque is a place where Muslims worship. However, in a wider concept, for many Muslims, a mosque is more than a place of worship. In a mosque Muslims worship, study, and discuss Islam and do many other things. 
A survey of literature on mosque suggests two different ideas of the mosques which are as a House of God and a Community Development Center (Khalit, 2011). At the first idea, mosque is a place where Muslims worship the God. Adult muslims perform five time prayers (shalat) at the mosque. For special prayer called Jumuah, Muslims are expected to do their their Friday prayer at the mosque. When a Muslim dies, a funeral prayer is normally held. During eclipses, mosques will host special prayers called eclipse prayers. There are also two main holidays in the Islamic calendar, eid al-fitri and eid al-adha.

In the holy month of Ramadhan, many events are performed in the mosque. During Ramadhan, Muslims fast during the day. After sunset mosque usually organize iftar. Some mosques will also hold meals in the morning before dawn. Mosque organizers will often invite poorer members of the community for these meals. Giving charity during Ramadhan is a very good deeds.

At the second idea, mosque is a place where Muslims activate mosques as Community Development Center. During the late of twentieth century, more and more mosques have been used for Community Development Center. Modern day mosques want to educate good citizens. The details differ greatly from mosque to mosque and from country to country.

Sheikh Omar Bakir Mohammed explained more detail in his book entitled The Role of the Mosque. He wrote that the very nature of the mosque dictates that it is central to the affairs of the Muslims. The Islamic shariah has determined that mosque is expected to play many important roles within the Muslim community, and the classical scholars have devoted considerable sections in book of Islamic Fiqh highlighting these roles.

According to Bakir Mohammed the roles of mosques in Islamic fiqh i.e. first mosque is expected to be the headquarters of the Islamic state's supreme leadership. It is also a center from where State's affairs are run. The Messenger of Allah used to meet envoys, sign agreements, judge between disputing parties and so on the mosque. The khaleefah would outline his policies and methods, and address and debate with his subjects directly without any fear of reprisal in the mosque. Second, the mosque is a section of the department of information and culture. The mosque is regarded as an important center for Islamic information for it is the scene of political, social, cultural, and ritual life. Mosque is considered to be one of most effective and successful means of da'wah and of giving information. Third, mosque is a judiciary court. Fourth, mosque is a university for learning and teaching. Fifth, the mosque is a platform for oratory, eloquence and poetry. Sixth, the mosque is a detention center for the prisoner of war. Seventh, the mosque is a place where war booties are divided. Eighth, 
the mosque is a hospital where casualties of war were treated. Ninth, the mosque is a home and refuge for the poor, needy, and the travelers. Tenth, the mosque is a place of relaxation and siesta. Eleventh, the mosque is a place where the pleasure of Allah and good reputation is sought. Twelfth, the mosque is an eating place for the hungry and the needy. Thirteenth, the mosque is a place for celebrations, socializing, and amusement. Fourteenth, the mosque is a place where people in need can ask for help. Fifteenth, the mosque is a place for consultation and exchanging views. Sixteenth, the mosque is a place of worship and prayer. Seventeenth, the mosque is a jami' ah holding the jumu' ah prayer and other popular gatherings. Eighteenth, the mosque is the best place to be and for i'tikaf. Nineteenth, the mosque is a place where some of the penal codes are implemented. Twentieth, the mosque was the first house built for mankind. (Bakir Mohammed, 8-9)

However, the functions of mosque in the present day generally concentrated on the physical appearance and disregard the essential role of the mosque. The functions of mosque today had become restricted to establishing the five prescribed prayers, and then it shuts it doors. Consequently, the mosque has become isolated from Muslim's real everyday life.

\section{Poverty Alleviation and People Empowerment in Islam}

Poverty has been defined in different ways by different people. Poor means a person and a state which has too little amounted asset and resources that he cannot meet the basic needs of living. Robert Chambers widened poverty from the limit of income and expenses to suddenly falling in economic hardship or probability to fall, insecurity, powerlessness and lonely situation (Md. Ismail Hossain, 2013: 121-122).

According to Islamic teaching, poverty is regarded as misfortune. Islam persuades against severe inequality and poverty and it has a serious attention in poverty alleviation. Allah has given plenty resources in the earth for living the human beings. Two verses of Qur' an (QS 7:10 and QS 62:10) and the prophet saying emphasize a personal obligation of a mankind to work and fulfil his needs through a well managed resource on earth, which is provided by Allah as a trust (amanah). Other verses of Qur' an (QS 70:24-25) states the importance of sharing the wealth with the needy to avoid large gap between the rich and the poor: "And those in whose wealth is recognised right, for the needy who asks, and him who is prevented (from some reason from asking)" (QS 70:2425). The word 'right' implies that Islam strongly emphasizes the obligation of the society, particularly the rich, to contribute actively in poverty alleviation. 
From the verses above it can be understood that there are two main methods for poverty alleviation in Islam. First, through people empowerment method. People empowerment means a process to increase the capability of people in achieving more welfare by relying on his own efforts (Ahmad Rofiq, 2005: 34). Begging is the least liked profession in Islam. The prophet of Allah, Muhammad purchased an axe and gave a man who came to beg so that he had not to beg. This hadith showed us that people empowerment is more important and must be put at the first order in poverty alleviation. Wealth development through productive way is the main order to realize Islamic goals i.e. minimizing the income gap and wealth ownership. It is a mistaken to primarily rely on redistribution system i.e. zakat, shadaqah, and waqaf at the first order (Chapra, 2008:50).

Second, through redistribution system i.e. zakat, shadaqah, and waqf. Zakah is the obligation to pay certain amount of wealth to the poor, thus certain amount of the assets of the well-off individuals is expected to be returned to the society with the notion that it is the right of the poor. On the other hand, waqf as an voluntary sector institution is an institutionalised charity aiming to deliver welfare services to the poor, it can be in the form of assets (such as land, building, car etc) or, becoming more commonly now, in cash waqf. In addition to the private sector contribution in alleviating poverty (Ahmed, 2004: 22).

Islamic redistribution system i.e. zakat, shadaqah, and waqf can cover the need of the poorest of the poor while the people empowerment programs can improve people ability to be economically independent. The Qur'an requires that wealth should not circulate only among the rich (Q.s. 59:7). This verse stressed the important of equitable distribution of income and wealth in society. This is because excessive differences in income and wealth tend to degrade those who are extremely poor and unable to utilize their full potential. Lack of an effective programme to reduce inequities is bound to destroy, rather than foster, the feelings of brotherhood that Islam wishes to promote. Hence, Islam not only requires the removal of poverty and fulfillment of everyone's needs, primarily through a respectable source of earning, but also emphasizes the social self-help programme of zakâh, sadaqat and awqaf along with equitable distribution of income and wealth.

\section{E. Poverty Alleviation through People Empowerment Pro- grams: Case Study of Masjid Al-Jihad Medan}

Masjid al-Jihad is located in Brayan Street exactly in the quarter of Yos Sudarso Street and Pulo Brayan Street. This mosque has a very long history and 
special place at the heart of Muslim society in Medan. In 2008 this mosque was recommended by the Major of Medan to be relocated to other place. The recommendation arose because the location of the mosque has been change. Once the neighborhood of the mosque was the Muslim's society but later changed into the traditional market. The location of the mosque then has been crowded by the traditional sellers surrounded of the mosque. There is Palapa Traditional Market behind the mosque.

The relocation has been cancelled because many Muslims opposed the recommendation of the Major of Medan. Even though the mosques had been burned down for the stove fire accident, but the Muslim society keep on fighting to keep the mosque and the rebuild the mosque to be three level building heights. Because of the struggling of Muslim society to keep the mosque, the relocation then cancelled.

This mosque then changed not only become the symbol of Islamic identity in Pulo Brayan but also become the source of funds for Muslim sellers that compete with Chinese sellers in Palapa Traditional Market. The Mosque of alJihad organizer aware that the majority of the sellers surrounding the mosque had been trapped under the regime of interest based rent seeking (well known as "rentenir"). They lend a number of money to the sellers and ask about 35$40 \%$ interest. This phenomenon has become a serious discussion among the Mosque of al-Jihad organizer. The rate of unemployment that occurs on the youth surrounding of the mosques also become a serious issue.

Based on above phenomenon, the Mosque of al-Jihad organizer agreed to establish Baitul Mal Wat Tamwil/BMT (small scale Islamic cooperative) in 2008 to solve the problem of money rent seeker and the youth unemployment rate. The organizer of the BMT came from the mosque organizer and the Mosque Youth Organization. The office of the BMT was built at the first floor of the mosque and serves the sellers and the mosque jamaah as small scale financial intermediary.

The Al-Jihad mosque BMT funded by the contribution of the founder obliged contribution (main saving and obligatory saving) and members voluntary contribution/saving. The BMT also accepted the charity in zakat, infaq, and shadaqah. Money from founder obliged contribution (main saving and obligatory saving) and members voluntary contribution/saving had been used in the productive contract mechanism. There are three productive funding contract mechanism used by the BMT. First, funding contract based on profit and loss sharing mechanism (mudharabah and musharakah). Second, funding 
contract based on sale and purchase on a commodity (murabahah, salam, and istisna'). Third, funding contract based on leasing mechanism (ijarah). Money from charity i.e. zakat, infaq, and shadaqah were used for soft loan mechanism (qard al-hasan) (Interview with Joni Yendra, the treasurer of Al-Jihad mosque BMT, 2014).

At first, the BMT focuses on the BMT members surrounding the mosque and fund the projects run by the members of the Mosque Youth Organization. According to the treasurer of the BMT (Joni Yendra), BMT Al-Jihad offers cheaper rate of margin to the sellers in order to eradicate the money rent seeker. The sellers had been exploited for quite a long time by the money rent seeker.

Most of the sellers surrounding the mosque are Muslims. Thus, many sellers that not the BMT members then apply for the funding programs and become the member of BMT. The asset of the BMT was almost reached 1 billion rupiah. The BMT served 300 sellers that open their stall surrounding the mosque and 200 sellers (almost 50\%) in the Palapa Traditional Market that located behind the mosque of Al-Jihad (Interview with Joni Yendra, the treasurer of Al-Jihad mosque BMT, 2014).

The al-Jihad mosque BMT now has become a good model in Medan for the mosque that involve in efforts to empower Muslim society and release the sellers from the debt trap.

\section{F. Promoting Mosques in Poverty Alleviation Strategies}

The success story of the Al-Jihad mosque in initiating poverty alleviation program through the establishment of BMT can be an inspiration in widening the functions of mosque. Many advantages will occur when mosque is being involved in people empowerment programs. First, the large number of mosques in Indonesia is a great source of economic empowerment potential. There are almost 1,000 mosques all around Indonesia. Imagine if the economic function of the Al-Jihad mosque BMT was replicated by other mosques in Indonesia, there will be more number of mosques that play the role not only as worship place but also play the role in eradicating poverty in Muslim's community.

Second, most of Muslim still have their trust on mosques. Generally, most muslim believe that the organizer of the mosque are trusted individuals. The high level of Muslim's community trust towards the mosque organizer is a great social capital to maximize the mosque function in empowering muslim's community. Muslim society in Indonesia are the majority of Indonesian citizens. 
The organizer of the mosque BMT have two options in raising fund from society. First, investment scheme. Many muslims have idle money. They usually put their idle money in the bank or any other investment instruments such as capital market instrumenst and insurance link investment. If fact, many muslim communities such as "perwiritan" or "majelis taklim" have idle money. Muslims who have this idle money can be persuaded by the mosque BMT organizer to be the BMT investors. The organizer of mosque BMT can convince the investors that their money will be safe and will be more useful because their money is used in term of shariah teaching i.e. to promote social welfare of Muslim society. This fund can be used for productive goals i.e. to fund the muslim business who needs capital to run and develop their (small) business.

Second, charity scheme. Many muslims are "aghniya" (the Have) who have obligation to pay zakat, and still have money that can be donated to many purposes. The conventional charity scheme usually treat the charity fund in one shot consumption target. This mode does not have multiplying effect. The organizer of mosque BMT can convince muslim's society to put their charity in a productive mode or in free interest consumption loan. The collective fund of zakat, infaq, and shadaqah will be distributed to the needy in soft loan mechanism (qard al-hasan). In this soft loan mechanism, the debtor will only pay the money back exatcly as much as their debt. They only pay more for the administration fee. This mode has multiplying effect and can felt widely by more muslim who need assistant through soft loan mechanism.

\section{G. Conclusion}

The traditional concept for mosque is usually merely understood as worship place for Muslims. Not many people aware that mosque can play more role for Muslim society especially as important instrument in poverty alleviation through people empowerment. Islam requires the removal of poverty and fulfilment of everyone's needs primarily through a respectable source of earning, and emphasizes the social self-help programme of zakâh, sadaqat and awqaf along with equitable distribution of income and wealth.

This paper showed that the empirical finding in the Al-Jihad BMT mosque support the thesis that mosque can play important role as key instrument in poverty alleviation through people empowerment. There are two main reason for this argument. First, the large number of mosque in Indonesia that almost 1,000 mosques all around Indonesia. If these mosques play the economic role like Al-Jihad BMT mosque program and strategies, this will be benefited for poverty alleviation in Muslim community. Second, people trust towards the 
mosque organizer will make it easier to raise investment fund as well as charity fund for the BMT mosques operation. By this way, poverty alleviation through people empowerment can be more maximized to reach the widespread of muslim community in Indonesia.

Poverty alleviation through people empowerment based on mosque BMT programs and strategies can be reconsidered to be national policy because mosques are the closest place for Muslim society sociologically and psychologically compared with other social institutions available in society. Inserting poverty alleviation through people empowerment based on mosque BMT programs and strategies will make possible more people to access the programs massively. This will contribute more effectively towards Indonesian economy in the future.

\section{REFERENCE}

Ahmed, Role of Zakah and Awqaf in Poverty Alleviation. Jeddah: Islamic Research and Training Insitute, Islamic Development Bank.

Akhtar, Muhammad Ramzan, "Poverty Alleviation on a Sustainable Basis in the Islamic Framework," The Pakistan Development Review, 39 : 4 Part II (Winter 2000).

Chapra, M. Umer, "The Islamic Vision of Development in the Light of Maqasid al-Shari'ah." Occassional Paper Series 15, The IIIT London-Washington (2008).

Choiruzzad, Shofwan Al Banna, "More Gain, More Pain: The Development of Indonesia's Islamic Economy Movement (1980s-2012)," Southeast Asia Program Publications at Cornell University, No. 95 (April 2013).

Hasibuan, Sayuti, "Poverty Alleviation: The Islamic Way," Seventh International Conference - The Tawhidi Epistemology: Zakat and Waqf Economy, Bangi: 2010.

Hossain, Md. Ismail, "Analysis on Poverty Alleviation by Mosque Based Zakat Administration in Bangladesh: An empirical study," Journal of Poverty, Investment and Development - An Open Access International Journal, Vol.1 2013.

Khalit, Nur Athirah, Revitalizing roles and Functions of mosques in Kuala Lumpur, Masters thesis, University Teknologi MARA, 2011. 
Pew Research's Center Religion and Public Life, "Muslim Population of Indonesia," downloaded from http://www.pewforum.org/2010/11/04/ muslim-population-of-indonesia/

Rofiq, Ahmad, et.al. Pemberdayaan Pesantren: Menuju Kemandirian dan Profesionalisme Santri dengan Metode Daurah Kebudayaan (Yogyakarta: PT LKiS Pelangi Aksara, 2005).

Sirageldin, Ismail, "Elimination of Poverty: Challenges and Islamic Strategies." Islamic Economic Studies, Vol. 8, No. 1, October 2000.

Yumna, Aimatul and Clarke, Matthew, "Integrating zakat and Islamic charities with microfinance initiative in the purpose of poverty alleviation in Indonesia." Proceeding 8th International Conference on Islamic Economics and Finance, Center for Islamic Economics and Finance, Qatar Faculty of Islamic Studies, Qatar Foundation. 